Article

\title{
Energy Saving Potential of Radiant Floor Heating Assisted by an Air Source Heat Pump in Residential Buildings
}

\author{
Yu-Jin Hwang and Jae-Weon Jeong *(D) \\ Department of Architectural Engineering, College of Engineering, Hanyang University, Seoul 04763, Korea; \\ reynahwang9497@gmail.com \\ * Correspondence: jjwarc@hanyang.ac.kr; Tel.: +82-2-2220-2370
}

Citation: Hwang, Y.-J.; Jeong, J.-W. Energy Saving Potential of Radiant Floor Heating Assisted by an Air Source Heat Pump in Residential Buildings. Energies 2021, 14, 1321. https://doi.org/10.3390/en14051321

Academic Editor: Fabio Polonara

Received: 4 January 2021

Accepted: 24 February 2021

Published: 1 March 2021

Publisher's Note: MDPI stays neutral with regard to jurisdictional claims in published maps and institutional affiliations.

Copyright: (c) 2021 by the authors. Licensee MDPI, Basel, Switzerland. This article is an open access article distributed under the terms and conditions of the Creative Commons Attribution (CC BY) license (https:// creativecommons.org/licenses/by/ $4.0 /)$.

\begin{abstract}
The objective of this research is to establish an appropriate operating strategy for a radiant floor heating system that additionally has an air source heat pump for providing convective air heating separately, leading to heating energy saving and thermal comfort in residential buildings. To determine the appropriate optimal operating ratio of each system taking charge of combined heating systems, the energy consumption of the entire system was drawn, and the adaptive floor surface temperature was reviewed based on international standards and literature on thermal comfort. For processing heating loads with radiant floor heating and air source heating systems, the heating capacity of radiant floor heating by $1^{\circ} \mathrm{C}$ variation in floor temperature was calculated, and the remaining heating load was handled by the heating capacity of the convective air heating heat pump. Consequently, when the floor temperature was $25^{\circ} \mathrm{C}$, all heating loads were removed by radiant floor heating only. When handling all heating loads with the heat pump, 59.2\% less energy was used compared with radiant floor heating only. Considering the local discomfort of the soles of the feet, the floor temperature is expected to be suitable at $22-23{ }^{\circ} \mathrm{C}$, and $31.5-37.6 \%$ energy saving compared with those of radiant floor heating alone were confirmed.
\end{abstract}

Keywords: radiant floor heating; air source heat pump; floor surface temperature; local discomfort; energy simulation

\section{Introduction}

Recently, in East Asian countries, the air heating approach with an air source heat pump as a residential heating system is attracting much interest because it has been considered as a renewable energy technology in Europe [1]. In Korea, hydraulic radiant floor heating with a gas-fired boiler releasing flue gas to the atmosphere has been commonly used for heating in most residential buildings, including high-rise apartment houses [2]. Radiant floor heating systems have an advantage in terms of thermal comfort, but their slow response to heating load variation $[3,4]$ is undesirable in current buildings as a heating system because it requires a fast or immediate response to the space heating demand [5].

In terms of thermal comfort, many researchers [6-9] have addressed that radiant floor heating systems are more thermally comfortable due to indirect heat transfer by less heated structures, resulting from the reduction in temperature difference. Imanari et al. [7] also conducted numerical simulations and experiments and concluded that a radiant ceiling panel system creates a more thermally comfortable environment. Sastry et al. [8] concluded that a properly designed radiant system has $18 \%$ fewer dissatisfied occupants than a variable air volume system. Al-Othmani et al. [9] found that radiative heating systems interact more with occupants; thus, the target thermal comfort is achieved in a shorter time compared with the convective system. However, as Lin et al. [10] and Sun et al. [11] argue, a convective heating system with a quick reaction is more comfortable than several other types of radiant heating systems; however, there are still some arguments against this idea and further studies are being conducted for its verification [12]. 
Meanwhile, it is also essential to reduce energy consumption in buildings using high-efficiency heating systems. Radiant heating systems have been considered as energyconservative heating systems $[7,8,13]$ for a while; however, recent studies $[10,14-16]$ have indicated that convective air heating systems consumed less energy than radiant floor heating systems as very efficient systems are developed such as heat pumps. Kim [14] also obtained the result that the convective heating system has the advantage of energy efficiency compared with the radiant heating system, which rather has strength in thermal comfort. Wang et al. [5] described that convective heating is more suitable for intermittent heating because radiant heating requires a higher heating capacity to offer preheating, and it takes time to heat because of its high thermal mass. Thus, it should be an appropriate heating solution in modern houses where the heating load is very low and needed to cover in a very short time. Martinopoulos et al. [15] considered that the heat pump airconditioning system was the best overall system from the investigated areas and could be coupled with renewable energy systems. Thus, it is necessary to provide a viable key for nearly net-zero-energy buildings.

In terms of the heating mechanism, radiant heating and convective heating have competitive and complementary relations, while there are limited studies addressing effective combinations of both heating systems that maximize the benefit of each system in terms of energy conservation. Consequently, in this study, to maximize the advantages of a radiant floor heating system and a convective air heating heat pump, we analyzed the operating strategies of the combined systems focused on the energy performance via a detailed energy simulation while considering the thermal comfort of occupants in a conditioned space. Desirable operating conditions and heating responsibility ratio of each system that provide the lowest primary energy consumption compared with the reference system are suggested.

\section{Entire System Overview}

The combined system proposed in this research (Figure 1) comprises a gas-fired boilerdriven radiant floor heating, an electric convective air heating heat pump, and a ventilator. An enthalpy recovery ventilator (ERV) was installed to supply the fresh ventilation air obligatorily required for the residential space.

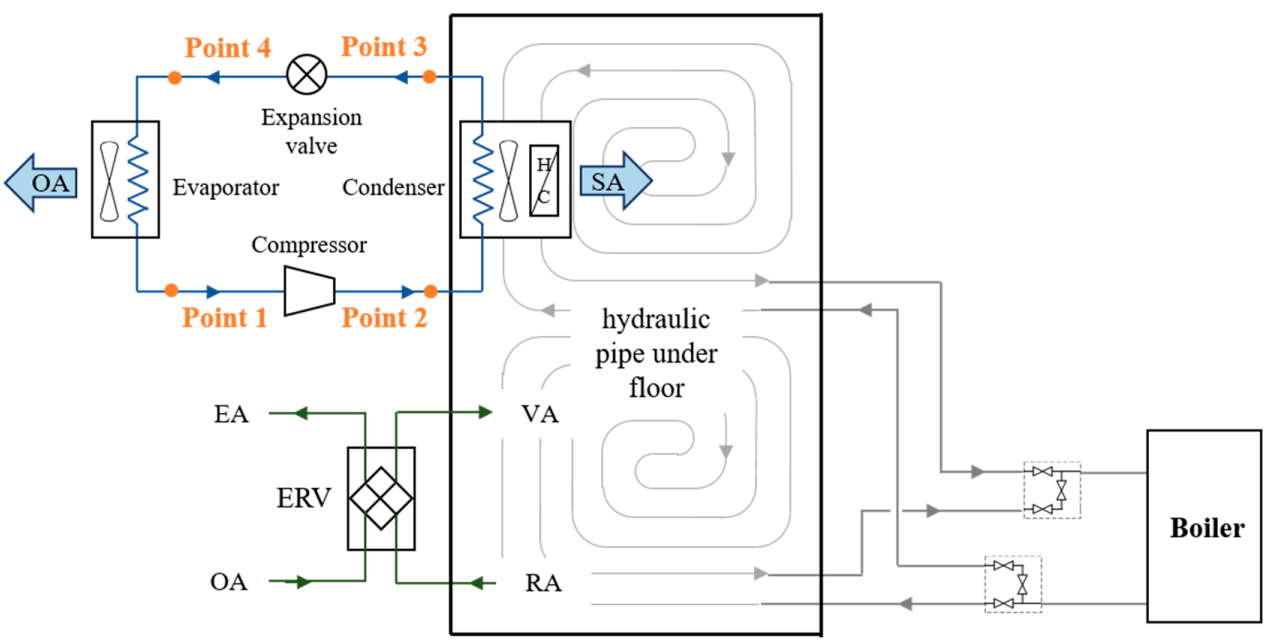

Figure 1. Schematic of the combined system. ERV: enthalpy recovery ventilator.

In the radiant floor heating system, a gas-fired boiler was used to produce hot water circulating in the radiant floor. The heat is transferred from hot water pipes embedded in a concrete slab and then released from the heated floor to the conditioned space via convective and radiative heat transfer. According to existing literature $[17,18]$, the heating capacity of radiant floor heating depends strongly on the spacing of the hot water pipes, diameter of the pipe, heat conductivity of the pipe, heat resistance of the slab, hot water 
temperature, and mass flow rate. These variables were reflected on simulation of heating capacity and energy calculation varied by floor temperature on following part.

Additionally, the deposited heat pump needs to accommodate the remaining heating load that is not met by the radiant floor under a different given operating condition by floor temperature. The heat pump reclaimed heat from the outside atmospheric air for space heating, so that freezing temperature conditions could affect the performance of the heat pump.

To supply fresh ventilation air to the conditioned residence with a minimized volume of preconditioned outdoor air, the enthalpy recovery ventilator was considered, which is a kind of dedicated outdoor air system (DOAS). The enthalpy exchanger reclaims heat and moisture from the exhaust air stream from the rooms and transfers them to the ventilation airside during the heating period.

\section{System Sizing}

\subsection{Design Heating Load of a Model Space}

In order to obtain the design (or peak) heating load for sizing the combined system, a $100 \mathrm{~m}^{2}$ model space conditioned was defined, and its physical parameters required for the hourly heating load estimation are summarized in Table 1 . The window-to-wall ratio, U-value, and room set-point conditions were determined by considering local design standards $[19,20]$. The hourly heating load profile of the model space for the heating period was obtained using a commercial building energy simulation program (i.e., TRNSYS 18).

Table 1. Physical parameters of the model space. rad: radiant heating, conv: convective heating.

\begin{tabular}{ccc}
\hline Location & Seoul, South Korea \\
\hline Volume & \multicolumn{2}{c}{$10 \mathrm{~m} \times 10 \mathrm{~m} \times 3 \mathrm{~m}, 300 \mathrm{~m}^{3}$} \\
\hline \multirow{2}{*}{ Indoor air condition } & \multicolumn{2}{c}{ Dry-bulb temperature $\left(T_{\text {zone }}\right)=20^{\circ} \mathrm{C}$} \\
\cline { 2 - 3 } Window-to-wall ratio & \multicolumn{2}{c}{ Relative humidity $(R H)=40 \%$} \\
\hline Occupants & \multicolumn{2}{c}{0.25} \\
\hline \multirow{2}{*}{ Internal heat gains } & Lights & $1.9 \mathrm{~W} / \mathrm{m}^{2}(\mathrm{rad}), 0.8 \mathrm{~W} / \mathrm{m}^{2}(\mathrm{conv})$ \\
\cline { 2 - 3 } & Equipment & $1.6 \mathrm{~W} / \mathrm{m}^{2}(\mathrm{rad}), 6.4 \mathrm{~W} / \mathrm{m}^{2}(\mathrm{conv})$ \\
\cline { 2 - 3 } & People & $50.5 \mathrm{~W} / \mathrm{person}(\mathrm{rad}), 50.5 \mathrm{~W} / \mathrm{person}(\mathrm{conv})$ \\
\hline U-value & Exterior wall & $0.117 \mathrm{~W} / \mathrm{m}^{2}$ \\
\cline { 2 - 3 } & Window & $0.95 \mathrm{~W} / \mathrm{m}^{2}$ \\
\hline \multirow{2}{*}{ Peak heating load } & Envelope & $3.7 \mathrm{~kW}$ \\
\cline { 2 - 3 } & Ventilation & $0.6 \mathrm{~kW}$ \\
\hline
\end{tabular}

The ventilation rate was determined based on the ASHRAE Standard 62.2 [21]. Because the ERV was applied in the model space, the hourly ventilation load $\left(\dot{Q}_{v e n t}\right)$ was estimated using Equation (1). The ventilation air temperature leaving the ERV ( $\left.T_{\text {erv }}\right)$ was determined using Equation (2) with the assumption that the sensible effectiveness of the ERV ( $\left.\varepsilon_{\text {erv }}\right)$ was $70 \%$ [22]. The calculated hourly ventilation load was added to the building's heating load profile. Consequently, the design (peak) heating load that the combined system must deal with was $4.3 \mathrm{~kW}$. Thus, all components of the combined system were sized to meet this design heating load.

$$
\begin{gathered}
\dot{Q}_{\text {vent }}=\rho_{o a} \cdot \dot{V}_{\text {vent }} \cdot c_{p} \cdot\left(T_{r a}-T_{\text {erv }}\right) \\
T_{\text {erv }}=T_{o a}-\varepsilon_{\text {erv }} \cdot\left(T_{o a}-T_{r a}\right)
\end{gathered}
$$




\subsection{Air Source Heat Pump Sizing}

The heating capacity of the heat pump was selected to meet the $4.3 \mathrm{~kW}$ design heating load of the model space. The design supply airflow rate of the heat pump $\left(\dot{V}_{s a, \text { design }}\right)$ was determined to be $1000 \mathrm{~m}^{3} / \mathrm{h}$ by considering the nominal supply airflow rates of several commercial heat pumps found in the market applicable to the model space [23]. Under the given design condition, the supply air temperature $\left(T_{s a}\right)$ of the heat pump was determined to be $34{ }^{\circ} \mathrm{C}$ using Equation (3) [24]. The condenser temperature ( $\left.T_{\text {cond }}\right)$ of the heat pump should be at least $40{ }^{\circ} \mathrm{C}$, as determined using Equation (4), when the heat exchange effectiveness $\left(\varepsilon_{\text {hex }}\right)$ between the condenser and return air from the conditioned space was $70 \%$, which is within the range of typical condenser temperatures for heating [25-27]. It was assumed that the auxiliary electrical resistance heater would be activated when the supply air temperature was lower than the setpoint temperature (i.e., $34^{\circ} \mathrm{C}$ ).

The evaporator temperature $\left(T_{\text {evap }}\right)$ was set to $-20^{\circ} \mathrm{C}$ to absorb sufficient heat from the outdoor air under the design condition (i.e., $-11.3^{\circ} \mathrm{C}$ ) [23]. The outdoor airflow rate at the evaporator $\left(\dot{V}_{e a}\right)$ was set to $1000 \mathrm{~m}^{3} / \mathrm{h}$. The heat exchange effectiveness between the evaporator and the outdoor air was assumed to be $70 \%$, and the evaporator leaving air temperature $\left(T_{e a}\right)$ was determined using Equation (5).

$$
\begin{gathered}
T_{s a}=\frac{L_{s e n}+L_{v e n t}}{\rho_{s a} \cdot c p_{a} \cdot \dot{V}_{s a, d s}}+T_{r a} \\
T_{\text {cond }}=\frac{T_{s a}-T_{r a}}{\varepsilon_{\text {hex }}} \\
T_{e a}=T_{o a}-\varepsilon_{\text {hex }} \cdot\left(T_{\text {evap }}-T_{o a}\right)
\end{gathered}
$$

The refrigerant used in the heat pump was R410A. Figure 2 shows the pressureenthalpy diagram of the heat pump cycle under the design operating condition. The process line of points 1-2 is the process at the compressor, points $2-3$ is the process at the condenser, points $3-4$ is at the expansion valve, and points $4-1$ is at the evaporator. Point 2 was determined using Equation (6) by applying a compression efficiency $\left(\eta_{c o m p}\right)$ of $75 \%$ [28].

$$
\begin{gathered}
h_{2}=\frac{h_{2, \text { ideal }}-h_{1}}{\eta_{\text {comp }}}+h_{1} \\
W_{\text {comp }}=G \cdot\left(h_{2}-h_{1}\right) \\
Q_{h p, \text { cond }}=G \cdot\left(h_{2}-h_{3}\right) \\
Q_{h \text {,evap }}=G \cdot\left(h_{1}-h_{4}\right)
\end{gathered}
$$

The impact of the inverter control of the compressor was considered by varying the refrigerant flow rate based on the heating demand [27]. The coefficient of performance of the heat pump was calculated using Equation (10). The power consumption of the heat pump $\left(P_{h p}\right)$ was calculated using Equation (11). Additionally, the horsepower of the compressor (PS) is provided in Equation (12). It was assumed that the mechanical efficiency of the compressor was $70 \%$. Consequently, the specifications of the heat pump selected for heating the model space are summarized in Table 2.

$$
\begin{gathered}
C O P_{h p}=Q_{h p, c o n d} / A W \\
P_{h p}=A W \cdot G \\
P S=\frac{A W * 0.239006 * G}{632 * \eta_{\text {mech }}}
\end{gathered}
$$




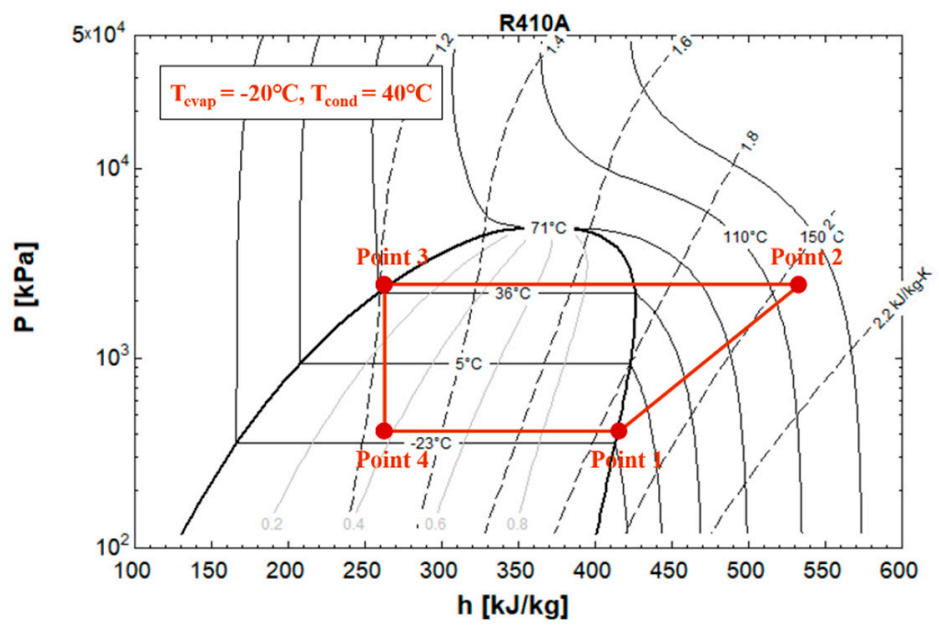

Figure 2. Pressure-enthalpy diagram of the designed heat pump.

Table 2. Specifications of the heat pump selected. COP: coefficient of performance.

\begin{tabular}{cc}
\hline Specification & Value \\
\hline Condensing temperature $\left(T_{\text {cond }}\right)$ & $40{ }^{\circ} \mathrm{C}$ \\
Evaporating temperature $\left(T_{\text {evap }}\right)$ & $-20{ }^{\circ} \mathrm{C}$ \\
Design condition of outdoor air & $-11.3{ }^{\circ} \mathrm{C}, 50 \%$ \\
Heating capacity & $4 \mathrm{~kW}$ \\
COP & 3.16 \\
Circulating refrigerant $(G)$ & $7 \mathrm{~kg} / \mathrm{h}$ \\
Nominal horsepower $(P S)$ & $2.5 \mathrm{PS}$ \\
\hline
\end{tabular}

\subsection{Radiant Floor Heating Sizing}

In this simulation, it is assumed that the radiant floor is sufficiently insulated without any heat loss to the outside of the radiant floor. Thus, hot water carrying heat through the hydraulic pipe transfers the entire potential heating capacity to the floor, and the heat is delivered to the room through the heated floor. The heat transfer rate of the radiant floor was calculated in steady-state thermal equilibrium. It was assumed that the supply water temperature $\left(T_{s w}\right)$ was $40{ }^{\circ} \mathrm{C}$, and the difference between supply and the return water $\left(T_{r w}\right)$ temperatures was $15^{\circ} \mathrm{C}$.

The total heating capacity of radiant floor heating $\left(Q_{R F H}\right)$ supplies the building heating load $\left(Q_{\text {load }}\right)$ with the assistance of the air-to-air heat pump $\left(Q_{H P}\right)$, as expressed in Equation (13). Regarding the hydraulic radiant floor, the heat transfer rate of the hydraulic radiant floor was controlled to vary the mass flow rate of the supply water $\left(\dot{m}_{w}\right)$. The specific heat of the water was also varied according to the water temperature.

$$
\begin{gathered}
\dot{Q}_{\text {load }}=\dot{Q}_{R F H}+\dot{Q}_{H P} \\
\dot{Q}_{R F H}=\dot{m}_{w} \cdot c_{p} \cdot\left(T_{s w}-T_{r w}\right)
\end{gathered}
$$

Furthermore, the total amount of heat transfer can be calculated considering the effect of convection heat transfer and radiation heat transfer regarding room air in the model building. In this study, because energy was simulated under a steady state, the average of unheated surface temperatures (AUST) was assumed to reach $20^{\circ} \mathrm{C}$, which is the room air temperature $\left(T_{a}\right)$ in the space (i.e., Equation (15)) $[29,30]$. Thus, the convective heat transfer coefficient and radiant heat transfer coefficient were integrated into the overall heat transfer coefficient $\left(h_{0}\right)$. The total amount of heat transfer rate was calculated using the heated surface area $\left(A_{\text {floor }}\right)$, overall heat transfer coefficient $\left(h_{o}\right)$, and the difference between the floor surface temperature and mean radiant temperature (MRT). MRT can be obtained using Equation (16) with the floor area $\left(A_{\text {floor }}\right)$, other structural surface areas $\left(A_{\text {wall }}\right)$, floor 
surface temperature $\left(T_{\text {floor }}\right)$, and the average of unheated surface temperatures (AUST) of walls and ceiling. The overall heat transfer coefficient $\left(h_{0}\right)$ was acquired using Equation (17) with floor surface temperature $\left(T_{\text {floor }}\right)$ and operative temperature $\left(T_{o p}\right)$, which can be found in DIN EN 1264-2 [31]. The overall heat transfer coefficient variation floor temperature is shown in Figure 3. The operative temperature of the model space was obtained as the arithmetic average of room temperature $\left(T_{a}\right)$ and mean radiant temperature $(M R T)$ [32] The settings and conditions in the simulation were referenced from previous research on acquiring floor surface temperature [33-35].

$$
\begin{gathered}
\dot{Q}_{R F H}=A \cdot\left\{h_{\text {rad }} \cdot\left(T_{\text {floor }}-A U S T\right)+h_{\text {conv }} \cdot\left(T_{\text {floor }}-T_{a}\right)\right\} \\
\dot{Q}_{R F H}=A_{\text {floor }} \cdot h_{o} \cdot\left(T_{\text {floor }}-M R T\right) \\
h_{o}=7.67 \cdot\left(T_{\text {floor }}-T_{\text {op }}\right)^{0.1} \\
M R T=\frac{T_{\text {floor }} \cdot A_{\text {floor }}+\text { AUST } \cdot A_{\text {wall }}}{A_{\text {total }}} \\
T_{o p}=\frac{T_{a}+M R T}{2}
\end{gathered}
$$

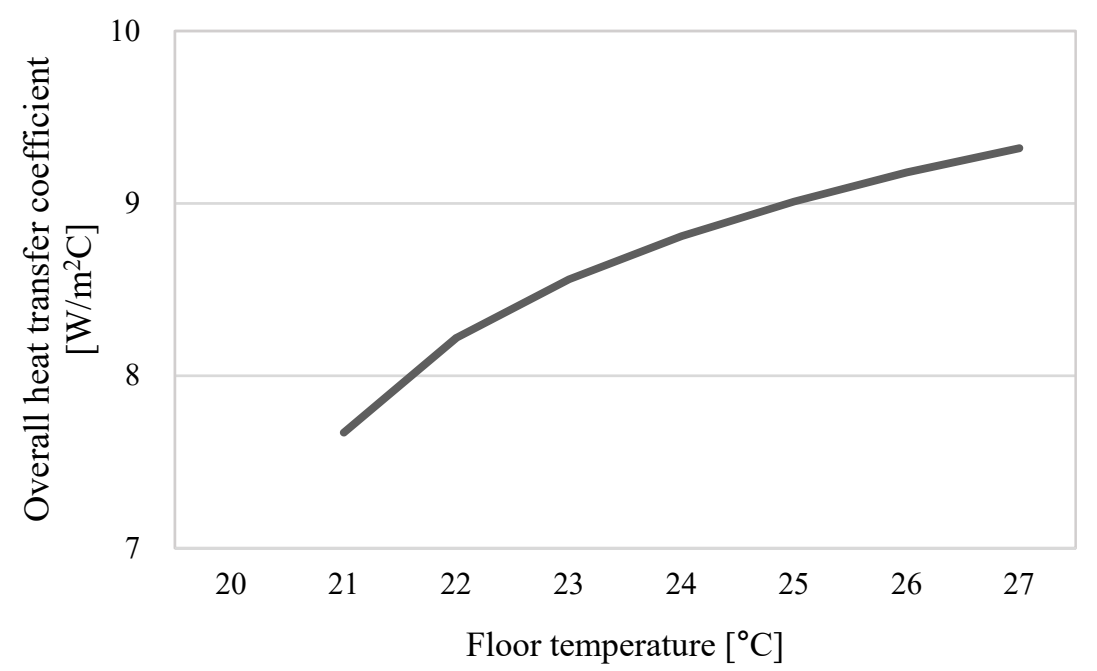

Figure 3. Overall heat transfer coefficient in radiant floor heating system.

\section{Energy Simulation}

\subsection{Air Source Heat Pump}

The flow rate of supply air $\left(\dot{V}_{s a \text {,present }}\right)$ was determined by the loads to be handled, as described in Equation (20). The effectiveness of the heat exchange $\left(\varepsilon_{\text {cond }}\right)$ between the condenser and return air from the conditioned room was set to $70 \%$, based on research on the heat exchange effectiveness [22]. The airflow rate of the exhaust at the evaporator $\left(\dot{V}_{e a}\right)$ was determined by the amount needed at the condenser using Equation (21). When the amount of heat from $1000 \mathrm{~m}^{3} / \mathrm{h}$ of outside air at the evaporator is insufficient compared to the amount needed at the condenser for the heating load, the auxiliary heater was switched on to heat the supply air. The components such as fans and auxiliary heaters were operated as the building load varied, and their energy consumption was determined to vary.

$$
\dot{V}_{s a, p r}=\frac{\dot{L}_{s e n}+\dot{L}_{v e n t}}{\rho_{s a} \cdot c p_{a} \cdot\left(T_{s a}-T_{r a}\right)}
$$




$$
\dot{V}_{e a}=\frac{\dot{Q}_{e v a p, a c} * G}{\rho_{e a} \cdot c p_{a} \cdot\left(T_{o a}-T_{e a}\right)}
$$

The heat exchange amounts at the evaporator and condenser were calculated on the air sides and the component sides. First, the amount of refrigerant $(G)$ needed to transfer sufficient heat to the condenser was calculated using Equation (22), dividing the heating capacity by the heating effect. The heating capacity $\left(Q_{a, \text { cond }}\right)$ is the same as the building load to be handled and the amount of heat exchange on the airside supplied to the room. The heating effect $\left(Q_{h p, c o n d}\right)$ can be obtained by the enthalpy difference from the pressureenthalpy diagram in Figure 2, corresponding to the heat dissipation in the condenser.

The cooling capacity $\left(Q_{a, \text { evap }}\right)$ and cooling effect $\left(Q_{\text {evap }, a c}\right)$ of the evaporator side was calculated using the circulating refrigerant. The cooling capacity $\left(Q_{a, \text { evap }}\right)$ indicates the amount of heat in the outdoor air cooled by the heat absorption of the evaporator, and it can be determined using the density of the air $\left(\rho_{o a}\right)$, its specific heat $\left(c p_{a}\right)$, its volume flow rate $\left(\dot{V}_{e a}\right)$, and the temperature difference between the front and back of the heat exchanger, as seen in Equation (25). The cooling effect $\left(Q_{\text {evap }, a c}\right)$ is the actual cooling amount of the evaporator, indicating the amount of heat the evaporator can absorb from the outdoor air with the circulating refrigerant $(G)$. Moreover, the cooling effect $\left(Q_{\text {evap }, a c}\right)$ can be obtained using Equation (23), by multiplying the enthalpy difference between points 1 and 4 by the flow rate of the circulating refrigerant.

The temperature of the outdoor air $\left(T_{e a}\right)$ exchanged in the evaporator can be obtained using Equation (24). The ambient air conditions used were calculated as $-11.3{ }^{\circ} \mathrm{C}$ and $50 \%$ according to the domestic design standard [19]. The heat exchange effectiveness $\left(\varepsilon_{\text {cond }}, \varepsilon_{\text {evap }}\right)$ of the condenser and evaporator was calculated to be $70 \%$ with reference to the preceding study [22].

$$
\begin{gathered}
G=\frac{\dot{Q}_{a, \text { cond }}}{q_{h p, \text { cond }}}=\frac{\dot{L}_{\text {sen }}+\dot{L}_{\text {vent }}}{h_{2}-h_{3}} \\
\dot{Q}_{\text {evap }, a c}=\dot{Q}_{h p, e v a p} \cdot G=\left(h_{1}-h_{4}\right) \cdot G \\
T_{e a}=T_{o a}-\varepsilon_{h e x} \cdot\left(T_{e v a p}-T_{o a}\right) \\
\dot{Q}_{H P}=\rho_{o a} \cdot \dot{V}_{e a} \cdot c p_{a} \cdot\left(T_{o a}-T_{e a}\right)
\end{gathered}
$$

\subsection{Boiler}

To process the required heating loads in a radiant heating system, a conventional gas boiler was used to supply hot water to the pipe under the floor. The boiler was operated to modulate the part-load ratio depending on the heating loads to be processed. The part-load ratio of the boiler is the ratio of the present heating load to the design heating capacity of the boiler, as reported in a previous paper [36].

The boiler energy $\left(Q_{\text {boiler }}\right)$ was calculated using the simple hot water boiler Equation (27), as suggested by EnergyPlus [37], which considers the efficiency of a boiler and the boiler efficiency performance curve (BEC) (i.e., Equation (26)). The efficiency of the boiler $\left(\eta_{\text {boiler }}\right)$ was $90 \%$ in this study [38]. The constants used in Equation (26) are described as follows:

$$
\begin{gathered}
C_{1}=0.626428326, \quad C_{2}=0.645643582, \quad C_{3}=-0.77720685, \quad C_{4}=0.313806701 \\
B E C=C_{1}+C_{2}\left(P L R_{\text {boiler }}\right)+C_{3}\left(P L R_{\text {boiler }}\right)^{2}+C_{4}\left(P L R_{\text {boiler }}\right)^{3} \\
\dot{Q}_{\text {boiler }}=\dot{Q}_{\text {load }} /\left(\eta_{\text {boiler }} \cdot B E C\right)
\end{gathered}
$$

\subsection{Model of Other Components}

\subsubsection{Fan}

As shown in Figure 1, two variable air volume fans were used-a supply fan and 
a return fan in the heat pump. The ERV also comprises two variable flow fans as a heat pump-a supply fan and a return fan.

The power of the variable flow fans was estimated using the general variable-airvolume fan power Equations (28)-(30) stated by ASHRAE 90.1 [39]. The part-load ratio of the variable flow fan is the ratio of the present airflow rate $\left(\dot{V}_{a, \text { present }}\right)$ to the design airflow rate $\left(\dot{V}_{a, \text { design }}\right)$. The efficiency of each fan was assumed to be $50 \%$. The total fan power was estimated to sum up every fan equipped in the heat pump and ventilation system, as shown in Equation (31).

$$
\begin{gathered}
P_{f a n, d s}=\frac{\rho_{r a} * \dot{V}_{a, d s} * P D}{\eta_{f a n}} \\
P L R_{f a n}=\frac{\dot{V}_{a, p r}}{\dot{V}_{a, d s}} \\
P_{f a n, p r}=P_{f a n, d s} *\left(0.0013+0.1470 * P L R_{f a n}+0.9506 * P L R_{f a n}^{2}-0.0998 * P L R_{f a n}^{3}\right. \\
P_{f a n, t o t a l}=P_{f a n, s a, p r}+P_{f a n, e a, p r}+P_{f a n, e r v, p r} * 2
\end{gathered}
$$

\subsubsection{Pump}

The radiant floor heating system comprises a pump for supplying hot water. The power of the pump was estimated using Equation (32), with variables such as density $\left(\rho_{w}\right)$, gravitational acceleration $(g)$, water flow rate $\left(\dot{V}_{\text {water }}\right)$, head loss $(H)$, and pump efficiency $\left(\eta_{\text {pump }}\right)$. The efficiency of the pump was set at $60 \%$, and head loss was assumed to be 20 , as reported in a previous study [40].

$$
P_{\text {pump }}=\left(\rho_{w} \cdot \dot{V}_{\text {water }} \cdot g \cdot H\right) / \eta_{\text {pump }}
$$

\subsubsection{Auxiliary Heater}

For the auxiliary heater, an electric heating coil was used in this research. As explained above, the heating coil was switched on only when the supply air could not reach the desired value. The heating capacity to process with the electric heating coil $\left(Q_{e h}\right)$ can be obtained using Equation (33).

$$
Q_{e h}=\left(Q_{e v a p, a c}-Q_{a, \text { evap }}\right) / 0.7
$$

\subsection{Turndown Ratio}

When the combined system was used to treat the heating load, the appropriate capacity of each component was estimated via simulation. To restrict the extreme capacity adjustment to the required load, the turndown ratio of each value in Table 3 was used for each component in the entire system.

$$
Q_{a c}=Q_{d s} * T D R
$$

Table 3. Turndown ratios.

\begin{tabular}{cc}
\hline Component & Value \\
\hline Heat pump & $0.25[41]$ \\
Boiler & $0.25[39]$ \\
Fan & 0.1 \\
Pump & 0.1 \\
\hline
\end{tabular}

\subsection{Adaptive Floor Temperature}

In order to share the heating rates of the two combined systems-radiant floor heating and heat pump systems - the former was operated by changeable floor temperature within 
acceptable ranges, and the remaining load was treated with the heat pump. This floor surface temperature is suggested in the following international standards: ISO 11855-1 of Europe [42] and ASHRAE Standard 55 of the United States [43]. They are mostly $19-29{ }^{\circ} \mathrm{C}$ for a sedentary, standing, or walking situation. These standards were based on early studies on thermal comfort [8,44-47]. In China, $24-30^{\circ} \mathrm{C}$ as the appropriate floor surface temperature has been proposed for designing radiant floor heating for various spatial purposes $[48,49]$. An upper limit of the surface temperature was also suggested in case of skin burns or discomfort, while a lower limit is not required. The Japanese committee on the radiant floor heating amenity also determined comfortable floor temperature and confirmed the upper and lower limits of floor temperature as $31^{\circ} \mathrm{C}$ and $25^{\circ} \mathrm{C}$, respectively [50].

However, countries such as Korea, where the radiant floor system has been used as the main heating method for a long time, have relatively higher standards regarding public awareness because of their living environment and established habits. Particularly, in Korea, the traditional radiant floor heating system called Ondol has a great effect on the Korean habits of heating. They are accustomed to higher floor temperatures compared with air, that is in the range of $30.6-38.8^{\circ} \mathrm{C}$ because radiant floor heating takes quite a long time to heat a room, and the insulation of outer rooms is not sufficient in ancient typical houses compared with contemporary houses [51].

However, in a warm indoor environment, floor temperature can be lowered to comply with the western standards because building loads are lowered with buildings becoming well-insulated and highly air-tight. In one study focused on floor surface temperature, the room air temperature was maintained at $20^{\circ} \mathrm{C}$. Thus, the comfortable floor temperature was in the range of $25-31.3^{\circ} \mathrm{C}$ [52]. Another study by Song et al. stated that the floor surface temperature in the low metabolism state is $23-33^{\circ} \mathrm{C}$ [53]. Via these researches, a distinct possibility was obtained for lowering floor surface temperatures when integrating convective air heating based on several studies.

\section{Simulation Results and Discussion}

\subsection{Energy Consumption by Floor Surface Temperature}

Energy simulations were conducted from December to March during the heating period of the simulation year, and the sum of the energy consumed during this period was added to the results. Figure 4 shows the primary energy consumption of each component with changes in floor temperature in the entire system, combined with radiant floor heating and a heat pump system. Primary energy factors of 2.75 for electricity and 1.1 for gas were used to convert the primary energy of each component. The heat pump, fan, pump, and auxiliary heater use electricity, while the boiler uses gas.

To provide radiant floor heating, the energy consumptions of the boiler and pump were computed. As the floor temperature increased by $1^{\circ} \mathrm{C}$, these components consumed more energy with a linear dimensional change, but the energy consumption of the boiler did not affect the low floor temperatures (i.e., $21^{\circ} \mathrm{C}$ and $22{ }^{\circ} \mathrm{C}$ ) because the boiler was affected by the turndown ratio. The remaining load in the conditioned zone after the radiant floor system removed some of the heating load was handled by a heat pump. In the air-to-air heat pump, the energy consumptions of the heat pump and fans in the evaporator and condenser were computed to provide the remaining load. As the floor temperature increased by $1^{\circ} \mathrm{C}$, these components in the convective heat pump consume less energy with a relatively proportional variation. Radiant floor heating and heat pump systems comprise components that are able to handle part loads such as inverter heat pumps, variable airflow fans, and water flow pumps. Therefore, the energy consumed by each component under the heating load tends to increase and decrease linearly. The energy consumption of fans in the ERV was also added to the total energy consumption of fans.

Overall, it was shown that energy consumption also increases with increasing temperature because the boiler in radiant floor heating consumes more energy than the compressor in the heat pump when dealing with the same load. When the floor temperature was $20^{\circ} \mathrm{C}$, all loads were treated with the heat pump system alone and consumed $8.5 \mathrm{MWh}$ in total, 
saving $59.2 \%$ compared with those at $25^{\circ} \mathrm{C}$, when all loads were treated with the radiant floor heating system.

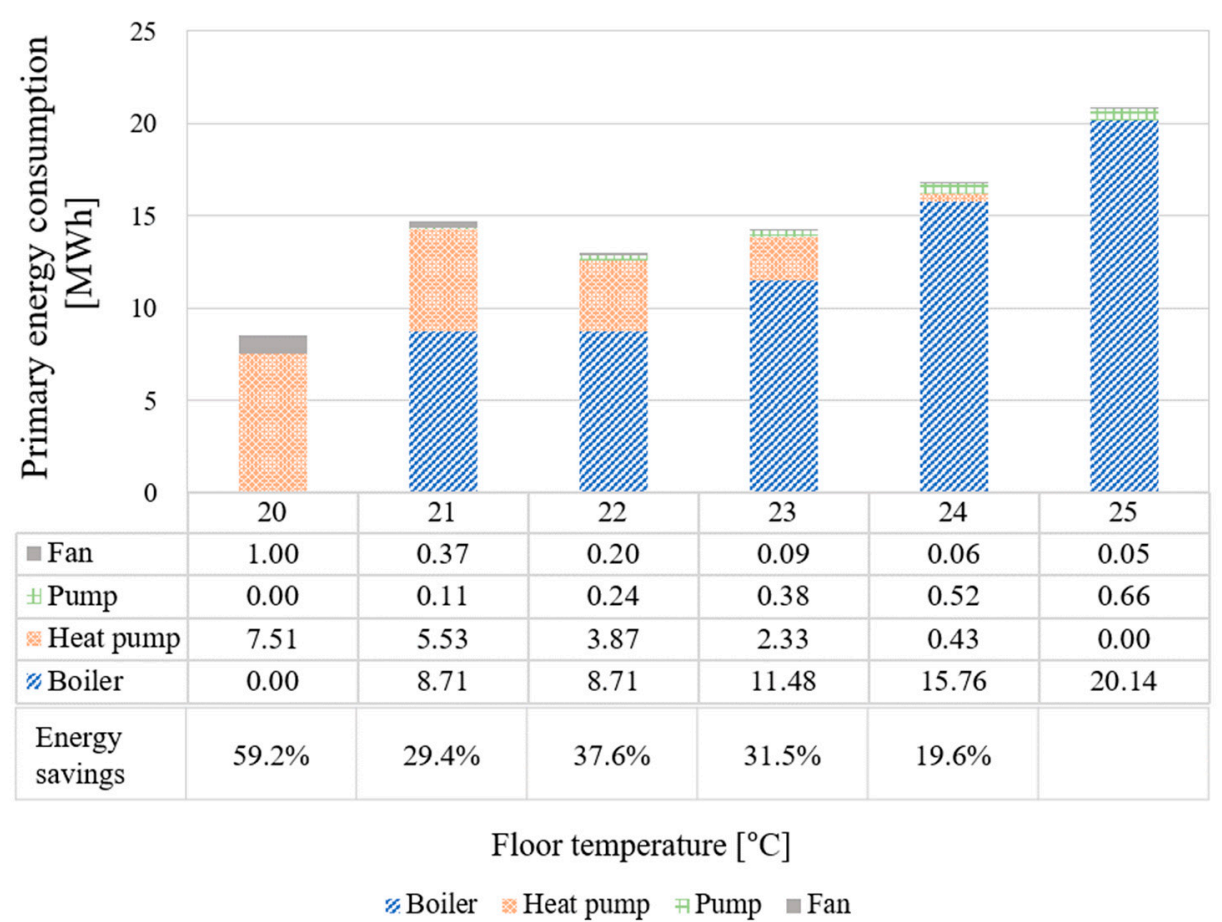

Figure 4. Primary energy consumption of the systems with variation in floor temperature.

\subsection{Heating Ratio of Two Heating Systems}

The heating charge ratios of radiant floor heating and the heat pump system with the variation in floor temperature are shown in Figure 5. When the floor temperature was $20{ }^{\circ} \mathrm{C}$, only the heat pump was operated to handle the indoor heating load. When the floor temperature was $25^{\circ} \mathrm{C}$, all the heating load could be removed with the radiant floor heating system alone. For radiant floor heating, a higher floor temperature (i.e., over $26^{\circ} \mathrm{C}$ ) was not necessary due to the low heating load of highly insulated and air-tight buildings. When the floor temperature was $22-23{ }^{\circ} \mathrm{C}$, the heating ratio of the heat pump handling was $14-43 \%$ of the total heating load. This can be applied to heat pumps and all kinds of convective air systems because the heating ratio denotes the amount of heating load that can be divided to take charge by two convective and radiant heating systems, resulting in different amounts of energy consumption.

\subsection{Discussion}

Concerning the acceptable floor temperature, previous researches have mostly proposed higher floor temperatures, which are described in the adaptive floor temperature chapter above; however, they are only purposed for radiant floor heating systems, and not radiant floor heating combined with other heating methods. Thus, the applicable range of International floor temperature standards (i.e., $19-29^{\circ} \mathrm{C}$ ) can be applied to the proposed combined heating system. Consequently, most recently built buildings, such as zero-energy buildings, are highly insulated and air-tight, and thus, they have a reduced load. Therefore, the heating load can be removed with a floor temperature of $25^{\circ} \mathrm{C}$. If air heating facilities are combined, the floor temperature can be reduced to $22-23{ }^{\circ} \mathrm{C}$ to lower the local discomfort of the foot while saving approximately $31.5-37.6 \%$ in energy in the case of the heat pump. 


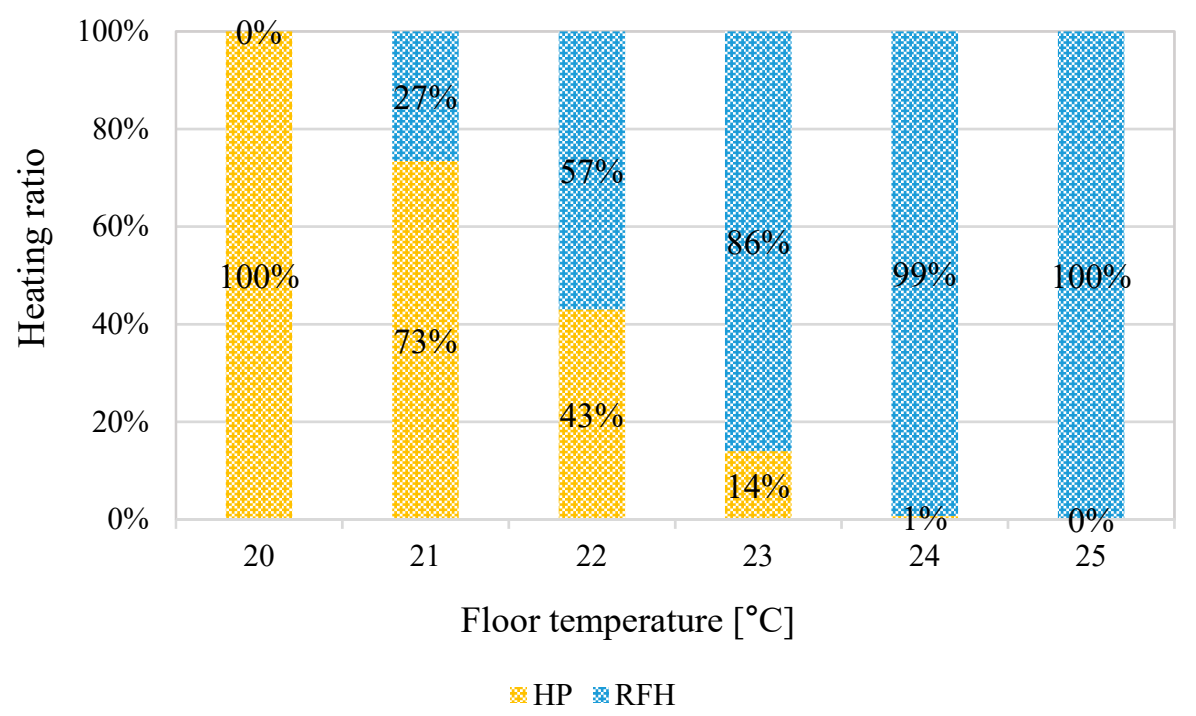

Figure 5. Heating charge ratio of the systems with variation in floor temperature. HP: convective air heating heat pump, RFH: radiant floor heating system.

\section{Conclusions}

This study extends heating methods using radiant and convective systems by taking advantage of efficient energy consumption and thermal comfort. In the combined system, a radiant floor heating system was combined with a convective air heat pump to accomplish these two purposes. To analyze the performance of the entire system, the primary energy consumption estimated as the floor temperature was varied by $1{ }^{\circ} \mathrm{C}$. Consequently, setting the floor temperature to $20^{\circ} \mathrm{C}$, the heat pump consumed 8.5 MWh of primary energy and saved $59.2 \%$ of the energy when setting the floor temperature to $25^{\circ} \mathrm{C}$. Moreover, the radiant floor heating system consumed 20.9 MWh of primary energy. When the floor temperature was set at $22-23^{\circ} \mathrm{C}$ considering local discomfort of the foot, the primary energy consumption decreased by $31.5-37.6 \%$, thus achieving both purposes simultaneously.

These integrated operation strategies considering floor discomfort and energy saving can be applied to apartment buildings in the upcoming future, where both radiant floor and convective air heating systems are established. However, depending on the lifestyles of occupants, whether mainly standing or sedentary, floor temperature can be adjusted, and energy-saving rates and heating ratio based on the floor temperature will be predictable through the simulation results of this study. Based on this research, an experimental study with detailed control logic for the systems is required in future studies.

Author Contributions: Conceptualization, J.-W.J. and Y.-J.H.; Methodology, Y.-J.H. and J.-W.J.; Investigation, Y.-J.H. and J.-W.J.; data curation, Y.-J.H.; writing-original draft preparation, Y.-J.H.; writing-review and editing, J.-W.J.; funding acquisition, supervision and project administration, J.-W.J. All authors have read and agreed to the published version of the manuscript

Funding: This work was supported by the National Research Foundation of Korea (NRF) grant (No. 2019R1A2C2002514) and Korea Institute of Energy Technology Evaluation and Planning (KETEP) grant funded by the Korea government (MOTIE)(No. 20202020800030).

Institutional Review Board Statement: Not applicable.

Informed Consent Statement: Not applicable.

Data Availability Statement: The data presented in this study are available on request from the corresponding author.

Conflicts of Interest: The authors declare no conflict of interest. 


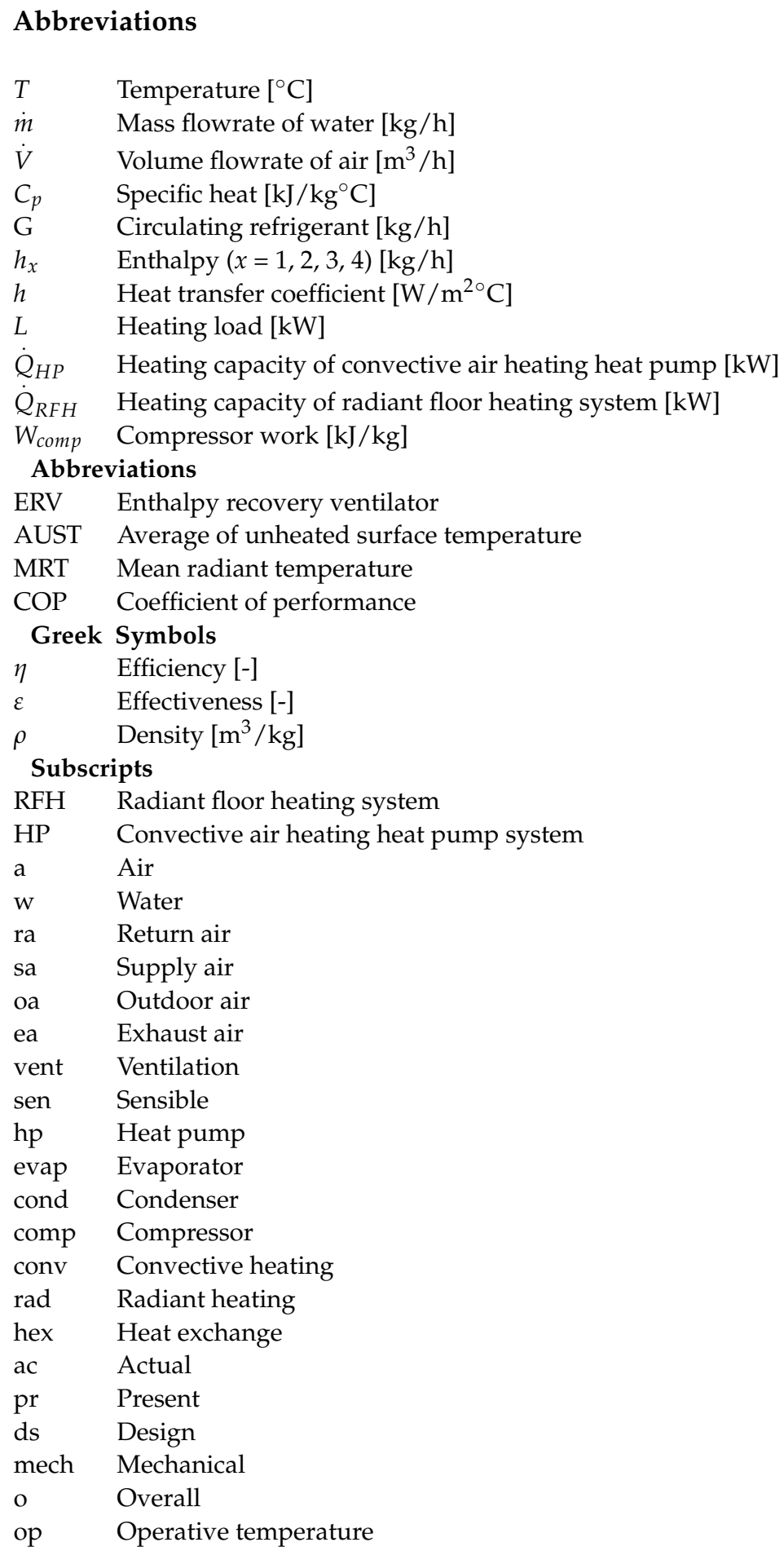

\section{References}

1. Hewitt, N.J.; Huang, M.J.; Anderson, M.; Quinn, M. Advanced air source heat pumps for UK and European domestic buildings. Appl. Therm. Eng. 2011, 31, 3713-3719. [CrossRef]

2. Chen, S.C.; Hsu, S.C.; Tsai, C.J.; Chou, C.C.K.; Lin, N.H.; Lee, C.T.; Roam, G.D.; Pui, D.Y.H. Dynamic variations of ultrafine, fine and coarse particles at the Lu-Lin background site in East Asia. Atmos. Environ. 2013, 78, 154-162. [CrossRef]

3. Dumont, O.; Quoilin, S.; Lemort, V. Experimental investigation of a reversible heat pump/organic Rankine cycle unit designed to be coupled with a passive house to get a Net Zero Energy Building. Int. J. Refrig. 2015, 54, 190-203. [CrossRef]

4. Shan, M.; Yu, T.; Yang, X. Assessment of an integrated active solar and air-source heat pump water heating system operated within a passive house in a cold climate zone. Renew. Energy 2016, 87, 1059-1066. [CrossRef]

5. Wang, Z.; Luo, M.; Geng, Y.; Lin, B.; Zhu, Y. A model to compare convective and radiant heating systems for intermittent space heating. Appl. Energy 2018, 215, 211-226. [CrossRef] 
6. Olesen, B.W.; Mortensen, E.; Thorshauge, J.; Berg-Munch, B. Thermal comfort in a room heated by different methods-technical paper. Los Angeles Meet. ASHRAE Trans. 1980, 86, 34-48.

7. Imanari, T.; Omori, T.; Bogaki, K. Thermal comfort and energy consumption of the radiant ceiling panel system. Comparison with the conventional all-air system. Energy Build. 1999, 30, 167-175. [CrossRef]

8. Sastry, G.; Rumsey, P. VAV vs. Radiant; Side-by-Side Comparison. ASHRAE J. 2014, 56, 17-24.

9. Al-Othmani, M.; Ghali, K.; Ghaddar, N. Experimental and theoretical study of transient human thermal comfort response in convective and radiative environments. HVAC R Res. 2009, 15, 855-873. [CrossRef]

10. Lin, B.; Wang, Z.; Sun, H.; Zhu, Y.; Ouyang, Q. Evaluation and comparison of thermal comfort of convective and radiant heating terminals in office buildings. Build. Environ. 2016, 106, 91-102. [CrossRef]

11. Sun, H.; Yang, Z.; Lin, B.; Shi, W.; Zhu, Y.; Zhao, H. Comparison of thermal comfort between convective heating and radiant heating terminals in a winter thermal environment: A field and experimental study. Energy Build. 2020, 224, 110239. [CrossRef]

12. Karmann, C.; Schiavon, S.; Bauman, F. Thermal comfort in buildings using radiant vs. all-air systems: A critical literature review. Build. Environ. 2017, 111, 123-131. [CrossRef]

13. Rhee, K.N.; Kim, K.W. A 50 year review of basic and applied research in radiant heating and cooling systems for the built environment. Build. Environ. 2015, 91, 166-190. [CrossRef]

14. Seon-Dong, K. An Experimental Study on the Improvement of Heating System in Apartment House. Master's Thesis, Chung-Ang University, Seoul, Korea, 2011.

15. Martinopoulos, G.; Papakostas, K.T.; Papadopoulos, A.M. Comparative analysis of various heating systems for residential buildings in Mediterranean climate. Energy Build. 2016, 124, 79-87. [CrossRef]

16. Park, B.; Jeong, Y.; Kim, G.; Ryu, S.-R.; Cheong, C. An experimental study on the heating performance evaluation of convection with radiant floor heating system. J. Air-Cond. Refrig. Acad. Present. Conf. 2019, 2, 138-141.

17. Shin, M.S.; Rhee, K.N.; Ryu, S.R.; Yeo, M.S.; Kim, K.W. Design of radiant floor heating panel in view of floor surface temperatures. Build. Environ. 2015, 92, 559-577. [CrossRef]

18. Jin, X.; Zhang, X.; Luo, Y.; Cao, R. Numerical simulation of radiant floor cooling system: The effects of thermal resistance of pipe and water velocity on the performance. Build. Environ. 2010, 45, 2545-2552. [CrossRef]

19. Kim, J.M.; Lee, G.C.; Lee, S.G.; Kim, M.S.; Min, J.K. An Effect of the Change of Orientation and Window Area Ratio upon Building Energy Requirement in Apartment Housings. J. Korea Inst. Ecol. Archit. Environ. 2013, 13, 21-26. [CrossRef]

20. Korea Ministry of Government Legislation. Available online: http:/ /www.law.go.kr/admRulSc.do?tabMenuId=tab107\&query= \%EC $\% 97 \% 90 \%$ EB $\% 84 \% 88 \%$ EC \%A7\%80\%EC\%A0\%88\%EC \%95\%BD\%EC\%84\%A4\%EA\%B3\%84\#liBgcolor0 (accessed on 20 December 2020).

21. Stevens, D.T.; Francisco, P.; Emmerich, S.J.; Baylon, D.A.; Brennan, T.M.; Crawford, R.R.; Delaquila, D.C.; Delaura, L.L.; Drumheller, S.C.; Fairey, P.W.; et al. ANSI/ASHRAE Standard 62.2-2013-Ventilation and Acceptable Indoor Air Quality in Low-Rise Residential Buildings ASHRAE; ASHRAE: Atlanta, GA, USA, 2013; p. 58.

22. Choi, Y.h.; Song, D.; Seo, D.; Kim, J. Analysis of the variable heat exchange efficiency of heat recovery ventilators and the associated heating energy demand. Energy Build. 2018, 172, 152-158. [CrossRef]

23. LG Electronics. B2B Catalog. Available online: http://kr.lgeaircon.com/gcac.cussupport.catalogue.RetrieveCatalogueList.dev; jsessionid=2cZvg62TjGh2rVy8pT0Rlnp4KJyNtgHTRQBh3hhDQCCgHT15c1QB!1504000692!-965517665 (accessed on 20 December 2020).

24. Byrne, P.; Ghoubali, R. Exergy analysis of heat pumps for simultaneous heating and cooling. Appl. Therm. Eng. 2019, 149, 414-424. [CrossRef]

25. Horn, J.F.; Scharf, P.H. Design Considerations for Heat Pump Compressors. Int. Compress. Eng. 1976, 92, $194-201$.

26. Jung, H.W.; Kang, H.; Chung, H.; Ahn, J.H.; Kim, Y. Performance optimization of a cascade multi- functional heat pump in various operation modes. Int. J. Refrig. 2014, 42, 57-68. [CrossRef]

27. Dechesne, B.J.; Tello-Oquendo, F.M.; Gendebien, S.; Lemort, V. Residential air-source heat pump with refrigerant injection and variable speed compressor: Experimental investigation and compressor modeling. Int. J. Refrig. 2019, 108, 79-90. [CrossRef]

28. Hundy, G.H.; Trott, A.R.; Welch, T.C. Refrigeration, Air Conditioning and Heat Pumps; Butterworth-Heinemann: New York, NY, USA, 1984; ISBN 9780081006474.

29. Acikgoz, O. A novel evaluation regarding the influence of surface emissivity on radiative and total heat transfer coefficients in radiant heating systems by means of theoretical and numerical methods. Energy Build. 2015, 102, 105-116. [CrossRef]

30. Koca, A.; Gemici, Z.; Topacoglu, Y.; Cetin, G.; Acet, R.C.; Kanbur, B.B. Experimental investigation of heat transfer coefficients between hydronic radiant heated wall and room. Energy Build. 2014, 82, 211-221. [CrossRef]

31. DIN. DIN EN 1264-2; Water Based Surface Embedded Heating and Cooling Systems-Part 2: Floor Heating: Prove Methods for the Determination of the Thermal Output Using Calculation and Test Methods; Beuth Verlag GmbH: Berlin, Germany, 2013.

32. Cholewa, T.; Anasiewicz, R.; Siuta-Olcha, A.; Skwarczynski, M.A. On the heat transfer coefficients between heated/cooled radiant ceiling and room. Appl. Therm. Eng. 2017, 117, 76-84. [CrossRef]

33. Wu, X.; Zhao, J.; Olesen, B.W.; Fang, L.; Wang, F. A new simplified model to calculate surface temperature and heat transfer of radiant floor heating and cooling systems. Energy Build. 2015, 105, 285-293. [CrossRef]

34. Zhang, L.; Liu, X.H.; Jiang, Y. Simplified calculation for cooling/heating capacity, surface temperature distribution of radiant floor. Energy Build. 2012, 55, 397-404. [CrossRef] 
35. Jin, X.; Zhang, X.; Luo, Y. A calculation method for the floor surface temperature in radiant floor system. Energy Build. 2010, 42, 1753-1758. [CrossRef]

36. Ministry of Land, Infrastructure and Transport. Available online: http://www.law.go.kr/\%ED $\% 96 \% 89 \%$ EC $\%$ A0\%95\%EA $\%$ B7\% $\%$ C\%EC \%B9\%99/\%EA\%B1\%B4\%EC\%B6\%95\%EB\%AC\%BC\%EC\%9D\%98\%EC \%97\%90\%EB\%84\%88\%EC\%A7\%80\%EC\%A0\%8 $8 \% \mathrm{EC} \% 95 \% \mathrm{BD} \% \mathrm{EC} \% 84 \% \mathrm{~A} 4 \% \mathrm{EA} \% \mathrm{~B} 3 \% 84 \% \mathrm{EA} \% \mathrm{~B} 8 \% \mathrm{~B} 0 \% \mathrm{EC} \% \mathrm{~A} 4 \% 80$ (accessed on 20 December 2020).

37. US Department of Energy. EnergyPlusTM Version 8.9.0 Documentation: Engineering Reference. Available online: https:// energyplus.net/sites/all/modules/custom/nrel_custom/pdfs/pdfs_v8.9.0/EngineeringReference.pdf (accessed on 20 December 2020).

38. Rhee, K.-N.; Jung, G.-J. Analysis of Heating Energy Saving Performance in Low-Energy Residential Buildings considering Boiler Part Load Efficiency. J. Air-Cond. Refrig. Acad. Present. Conf. 2019, 1, 736-739.

39. Wilson, R.D.; Cales, B. ANSI/ASHRAE/IES Standard 90.1-2013 (S-I Edition): Energy Standard for Buildings Except Low-Rise Residential Buildings; American Society of Heating, Refrigerating and Air-Conditioning Engineers: Atlanta, GA, USA, 2013 ; pp. $404-636$.

40. Dong, H.W.; Lee, S.J.; Yoon, D.S.; Park, J.Y.; Jeong, J.W. Impact of district heat source on primary energy savings of a desiccantenhanced evaporative cooling system. Energy 2017, 123, 432-444. [CrossRef]

41. Danfoss Co. Ltd. Advanced Efficiency, Precision Cooling: Design an HVAC System Like No Other. Available online: https://assets. danfoss.com/documents/DOC270839957144/DOC270839957144.pdf (accessed on 20 December 2020).

42. ISO. International Standard ISO 11855-1. Building Environment Design-Design, Dimensioning, Installation and Control of Embedded Radiant Heating and Cooling Systems_Part 1: Definition, Symbols, and Comfort Criteria; ISO: Geneva, Switzerland, 2012.

43. ASHRAE. ANSI/ASHRAE/IES Standard 55-2013: Thermal Environmental Conditions for Human Occupancy; ASHRAE: Atlanta, GA, USA, 2013; ISSN 1041-2336.

44. Fanger, P.O.; Ipsen, B.M.; Langkilde, G.; Olessen, B.W.; Christensen, N.K.; Tanabe, S. Comfort limits for asymmetric thermal radiation. Energy Build. 1985, 8, 225-236. [CrossRef]

45. Hoof, V.; Fanger, P.O. Assessment of Thermal Comfort. Br. J. Ind. Med. 1973, 84, 313-324.

46. Olesen, B.W. Thermal Comfort Requirements for Floors Occupied By People With Bare Feet. ASHRAE Trans. 1977, 83, 41-57.

47. Zhang, A. Human Thermal Sensation and Comfort in Transient and Non-Uniform Thermal Environments. Ph.D. Dissertation, University of California, Berkeley, CA, USA, 2003.

48. China Institute of Building Standard Design and Research. National Technical Measures for Design of Civil Construction Engineering; CBS: Beijing, China, 2009.

49. Lu, X.; Liu, H.; Wu, Y. Acceptable surface temperature of floor radiant heating system based on thermal comfort study in southern China. E3S Web Conf. 2019, 80, 1-7. [CrossRef]

50. Zhang, L.; Emura, K.; Nakane, Y. A proposal of optimal floor surface temperature based on survey of literatures related to floor heating environment in Japan. Appl. Human Sci. 1998, 17, 61-66. [CrossRef]

51. Jang-Yeul, S. The state of thermal sensation researchers in Korea and thermal comfort in Ondol space. In Proceedings of the 10th Symposium on Human-Environment System, Stockholm, Sweden, 5-14 June 1986.

52. Song, G.S. Effect of floor surface temperature on blood flow and skin temperature in the foot. Indoor Air 2008, 18, 511-520. [CrossRef] [PubMed]

53. Song, G.S.; Ju, T.S. Changes in the scrotal temperature of subjects in a sedentary posture over a heated floor. Int. J. Androl. 2006, 29, 446-457. [CrossRef] [PubMed] 